\title{
PROMINENT FACTORS OF ETREPRENEURIAL SELF-EFFICACY IN WEST JAVA: COMPARISON BETWEEN MEN AND WOMEN ENTREPRENEUR
}

\author{
Wiendy Puspita SARI ${ }^{1}$ * \\ Puteri Andika SARI ${ }^{2}$ \\ Dito RINALDO ${ }^{3}$
}

\begin{abstract}
Received: October 2021 | Accepted: November 2021 | Published: December 2021
Please cite this paper as: Sari, W.P., Sari, P.A., Rinaldo, D. (2021) Prominent factors of entrepreneurial self-efficacy in West Java: comparison between men and women entrepreneur, Holistica Journal of Business and Public Administration, Vol. 12, Iss. 3, pp.54-68
\end{abstract}

\begin{abstract}
Entrepreneurial Self-Efficacy (ESE) is important for entrepreneurs to build and maintain their business. The research purposes are to delve more about the components of ESE in West Java and the difference of these components between men and women entrepreneurs. West Java is one of province in Indonesia (Developing Country) that has high growth of High School and Medium Enterprises (SME's). This study used quantitative approached. A questionnaire was spread to 52 entrepreneurs in West Java for gathering data. Soft Modelling method named Partial Least Square was used in this study. Predictors of ESE are Entrepreneurial Knowledge, Entrepreneurial Experiences, Instrumental Readiness, Risk Propensity. Findings will be discussed deeply in discussion section of this study. The result of this study confirm the prominent factors that influence ESE positively and how each factor affect men and women entrepreneurs

Keywords: entrepreneurial self-efficacy, entrepreneurial experiences, entrepreneurial knowledge, instrumental readiness, risk propensity
\end{abstract}

\section{Introduction}

Early in 2019, Covid 19 was determined to be a new kind of respiratory disease. It has spread all across the world, resulting in a worldwide pandemic. It is still evolving and spreading over the globe. Covid 19 has lately produced a new variant called "Delta,"

1 Sekolah Tinggi Ilmu Ekonomi Ekuitas, St. P.H.H Mustafa No.31, Bandung, Indonesia, wiendy.ps@gmail.com

* Corresponding author

2 Sekolah Tinggi Ilmu Ekonomi Ekuitas, St. P.H.H Mustafa No.31, Bandung, Indonesia, puteri.andika31@gmail.com

3 Sekolah Tinggi Ilmu Ekonomi Ekuitas, St. P.H.H Mustafa No.31, Bandung, Indonesia, rinaldo.dito09@gmail.com 
which is more dangerous than the prior version (CNN Indonesia). Not only does Covid 19 have an impact on human health, but it also has an impact on worldwide trade. Ones of all levels, from major multinationals to small businesses, were decimated by this epidemic. Businesses are finding it difficult to survive in this pandemic since a variety of commercial operations are prohibited in order to prevent the virus from spreading. Lockdown is also required in some factories.

Covid-19 has wreaked havoc on Indonesia, which is one of the poor countries worst hit. The Government Statistic Department ("Badan Pusat Statistik" in Indonesia) estimated that Indonesia's economy will contract by $-2,07$ percent in 2020 , with GDP of Rp 15.434,2 billion and National Income of $\mathrm{Rp} 56,9$ million (nasional.kontan.co.id, downloaded on July 1, 2021). Large-Scale Social Restrictions ("Pembatasan Sosial Berskala Besar"), a government policy enacted to mitigate the deployment of the Covid19, reduced economic activity in Indonesia and caused the GDP to fall. Population growth, on the other side, has grown. During the epidemic, the birth rate increased. The drop in economic activity and the rise in population have resulted in a decrease in national income.

Figure 1 Indonesia's Gross Domestic Product (GDP) per capita in 2015 - 2020

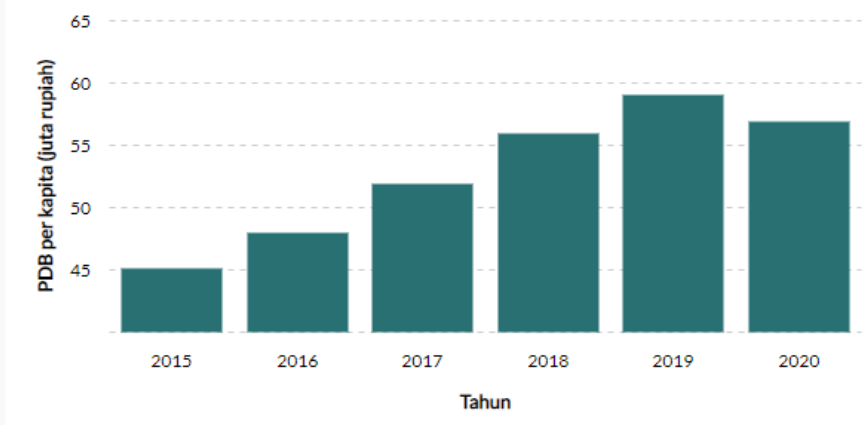

Pendapatan per kapita (juta rupiah)

Source : (Lokadata.id, 2021)

In 2020, Indonesia's Gross Domestic Product (GDP) per capita fell by Rp. 2.2 million to Rp. 56.9 million, or US\$3,911.7, down from Rp. 59.07 million the previous year. The impact of the Covid-19 epidemic is this drop. Indonesia's GDP per capita is still below US\$4,000, putting it in the lower middle income group. On the other side, this is related to population growth. (lokadata.id, downloaded 1/7/2021).

Indonesia's 2020 Economy Down By 2.07 Percent (c-to-c), following the graph of GDP experienced by Indonesia from 2014-2020. The following is an explanation of the decline in the form of pictures: 
HOLISTICA Vol 12, Issue 3, 2021, pp.54-68

Figure 2 Indonesia's Economic Growth in 2020

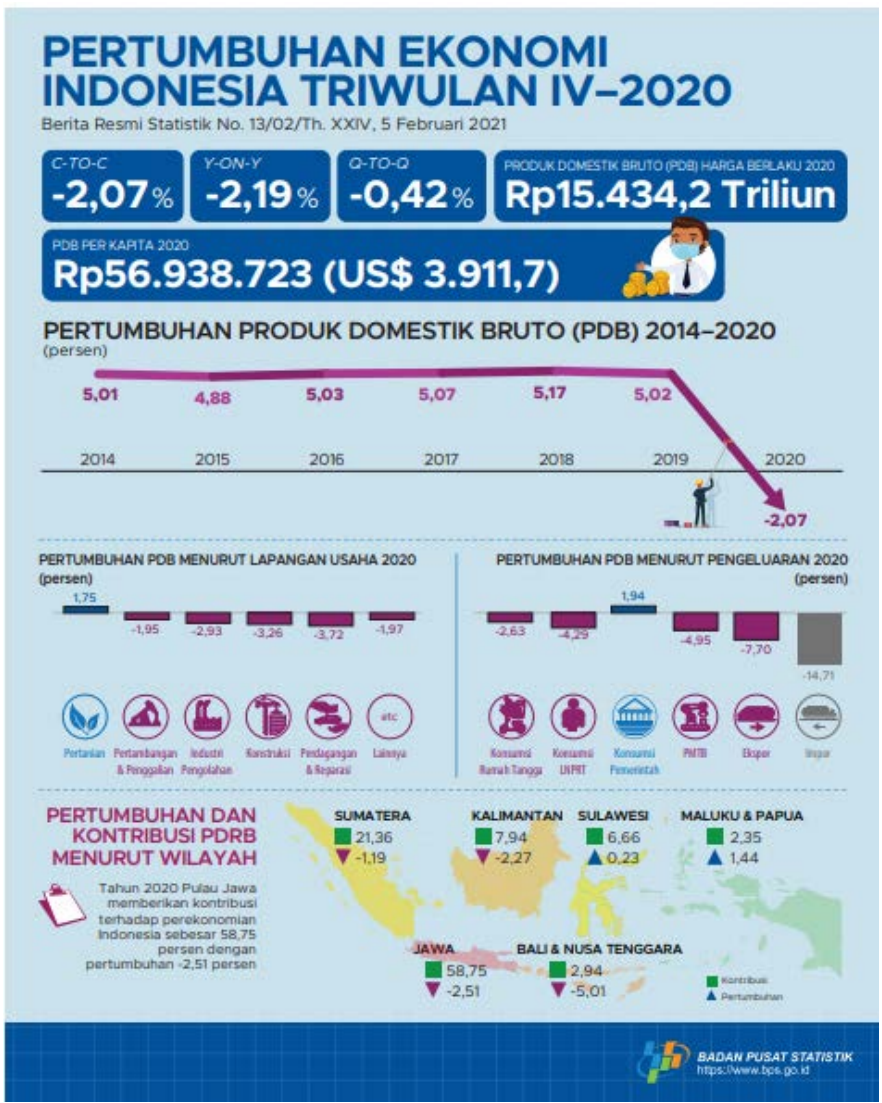

Source : (BPS.go.id, 2021)

Figure 3 Population Growth in Indonesia

\begin{tabular}{|c|c|c|c|c|c|c|c|c|c|c|c|c|}
\hline Year & Population & $\begin{array}{c}\text { Yearly } \\
\% \\
\text { Change }\end{array}$ & $\begin{array}{l}\text { Yearly } \\
\text { Change }\end{array}$ & $\begin{array}{l}\text { Migrants } \\
\text { (net) }\end{array}$ & $\begin{array}{c}\text { Median } \\
\text { Age }\end{array}$ & $\begin{array}{l}\text { Fertility } \\
\text { Rate }\end{array}$ & $\begin{array}{l}\text { Density } \\
\left(\mathrm{P} / \mathrm{Km}^{2}\right)\end{array}$ & $\begin{array}{c}\text { Urban } \\
\text { Pop } \\
\%\end{array}$ & $\begin{array}{c}\text { Urban } \\
\text { Population }\end{array}$ & $\begin{array}{l}\text { Country's } \\
\text { Share of } \\
\text { World Pop }\end{array}$ & $\begin{array}{c}\text { World } \\
\text { Population }\end{array}$ & $\begin{array}{l}\text { Indonesia } \\
\text { Global } \\
\text { Rank }\end{array}$ \\
\hline 2020 & $273,523,616$ & $1.07 \%$ & $2,898,047$ & $-98,955$ & 29.7 & 2.32 & 151 & $\begin{array}{r}56.4 \\
\%\end{array}$ & $154,188,546$ & $3.51 \%$ & $7,794,798,739$ & 4 \\
\hline 2019 & $270,625,668$ & $1.10 \%$ & $2,955,025$ & $-98,955$ & 28.8 & 2.42 & 149 & $\begin{array}{r}55.8 \\
\%\end{array}$ & $150,900,390$ & $3.51 \%$ & $7,713,468,100$ & 4 \\
\hline 2018 & $267,670,543$ & $1.14 \%$ & $3,019,580$ & $-98,955$ & 28.8 & 2.42 & 148 & $\begin{array}{r}55.1 \\
\%\end{array}$ & $147,603,006$ & $3.51 \%$ & $7,631,091,040$ & 4 \\
\hline 2017 & $264,650,963$ & $1.18 \%$ & $3,094,582$ & $.98,955$ & 28.8 & 2.42 & 146 & $\begin{array}{r}54.5 \\
\%\end{array}$ & $144,294,861$ & $3.51 \%$ & $7,547,858,925$ & 4 \\
\hline 2016 & $261,556,381$ & $1.23 \%$ & $3,173,125$ & $.98,955$ & 288 & 2.42 & 144 & $\begin{array}{r}539 \\
\%\end{array}$ & $140,972,925$ & $350 \%$ & $7,464,022,049$ & 4 \\
\hline 2015 & $258,383,256$ & $1.33 \%$ & $3,309,808$ & $-90,889$ & 28.5 & 2.45 & 143 & $\begin{array}{r}53.3 \\
\%\end{array}$ & $137,634,761$ & $3.50 \%$ & $7,379,797,139$ & 4 \\
\hline 2010 & $241,834,215$ & $1.34 \%$ & $3,108,949$ & $-266,737$ & 27.2 & 2.50 & 133 & $\begin{array}{r}50.1 \\
\%\end{array}$ & $121,052,980$ & $3.48 \%$ & $6,956,823,603$ & 4 \\
\hline 2005 & $226.289,470$ & $1.36 \%$ & $2,955,129$ & $-229,931$ & 25.6 & 2.53 & 125 & $\begin{array}{r}46.0 \\
\%\end{array}$ & $104,155,654$ & $3.46 \%$ & $6,541,907,027$ & 4 \\
\hline
\end{tabular}

Source : (Worldometers.info, 2021)

According to Worldometer's elaboration of the most recent United Nations statistics, Indonesia's current population is $276,477,807$ as of Sunday, July 11,2021 . According to 
UN estimates, Indonesia's population in 2020 will be 273,523,615 people. Indonesia's population accounts for 3.51 percent of the world's total. Indonesia is ranked fourth in terms of population among nations (including dependent territories). (worldometers.info, 2021).

Covid-19 smashed several aspects of Indonesia's economy. Tourism is one of the worstaffected sectors. Tourism is one of Indonesia's most important sources of revenue since it generates a lot of foreign currency. West Java, particularly Bandung, is a popular tourist destination in Indonesia.

Covid-19 affected about $87.5 \%$ of Micro Small Medium Enterprises (MSMEs) in Indonesia, and around 93.2\% of them affected on the sales side (Bisnis.com, 2020). Based on data from the MSMEs Department of West Java ("DINAS KUK JAWA BARAT" in Indonesia), 98\% of 4.6 million SMEs in West Java are micro and high school businesses and their income decrease drastically about 80\% during Covid-19. (Tagar.id, 2021).

In the previous six years, the MSMEs Department of West Java has documented a 3.8 percent increase in MSMEs in the city of Bandung. However, the Covid-19 epidemic has had an influence on a number of Bandung City's most important goods, owing to decreasing market demand as a result of the pandemic. According to statistics from the Government Statistics Department, there are 111,627 micro-enterprises, accounting for $75 \%$ of the total number of MSME groupings $(147,073)$. There are 6,409 registered aided MSMEs with the MSMEs Department. (JabarEkspres.com, 2021). The Covid-19 epidemic is expected to harm 6,000 Micro, High School, and Medium Enterprises (MSMEs) in Bandung. The service sector MSMEs are the most affected, according to data from Bandung City's MSMEs Department. Furthermore, compared to pre-pandemic levels, the fashion industry's average turnover fell by 79 percent. While the culinary industry accounts for 65 percent of all jobs. (Bisnis.com, 2020)

The owner's competency and self-confidence might have an impact on the firm. Selfconfidence, in addition to expertise, is critical for business survival in a variety of conditions. One of the keys to company success is entrepreneurial self-efficacy. Entrepreneurial Self-Efficacy is influenced by a number of characteristics, including entrepreneurial knowledge, entrepreneurial experiences, instrumental readiness, and risk proclivity. To determine which of the many elements that drive entrepreneurial selfefficacy is the most significant, a research titled Prominent Factors of Entrepreneurial Self-Efficacy in West Java: Comparison between Men and Women Entrepreneurs was done.

As a result, the research's purpose is to examine more about the impact of entrepreneurial knowledge, experiences, instrumental readiness, and risk proclivity on entrepreneurial self-efficacy. The following is the formulation of the problem from the research of this scientific work, based on the background of the study that has been presented: 
1. How influences of Entrepreneurial Knowledge on the Entrepreneurial Self-Efficacy?

2. How influences of Entrepreneurial Experiences on the Entrepreneurial Self-Efficacy?

3. How influences of Instrumental Readiness on the Entrepreneurial Self-Efficacy?

4. How influences of Risk Propensity on the Entrepreneurial Self-Efficacy?

\section{Literature Review}

Self-Efficacy is interesting subject to be studied for the past few decades (Kazeem \& Asimiran, 2016). According to (Krueger \& Brazeal, 1994), there are correlation between self-efficacy and personal control \& competence. Self-Efficacy can alter failures into learning experiences. According to (Pihie \& Bagheri, 2010), entrepreneurial self-efficacy (ESE) can help entrepreneur to achieve success.

Based on (Chen, Greene, \& Crick, 1998) Entrepreneurial self-efficacy (ESE) can be interpreted as self-confidence to build and run business successfully. Self-efficacy can predispose individual preference of activities, goals, level of persistence and performance (Hao, Scott, \& Gerald, 2005).

Due to growth women owned firm affect socio development, gender become notable element in ESE (Coleman \& Kariv, 2014). World Bank Data in 2014 showed that Micro Small Medium Enterprises (MSME's) which are owned by female entrepreneurs are around $40 \%$. Female entrepreneurs have some characteristic such as courage, confidence, and strong will in doing business (Gano-an J. C., 2020).

Several literatures suggests that women are more passive in taking entrepreneurial action and expressing business intentions (Baughn, Cao, Le, Lim, \& Kent, 2006). Successful business can be developed through learning knowledge, skills, expertise of the entrepreneurs (Rae \& Carswell, 2000). According to (Minniti \& Bygrave, 2001), Basically entrepreneurship is a learning process; so It's important to understand comprehensive knowledge of entrepreneurship in doing business.

According to (Puni, Anlesinya, \& Korsorku, 2018) Entrepreneurship Educations such as opportunity recognition and entrepreneurship knowledge have positive and significant effect on Entrepreneurial Self-Efficacy. Entrepreneurial knowledge is individual's skills and concepts during start up and development of business (Alberti, 1999).

Individuals need experience in cognitive and social growing (Bandura, 1982). Positive and negative outcomes of actions can be recognized through experience (Boyd \& Vozikis, 1994). Direct experience in developing ideas, implementing ideas gaining feedback can lead individual to Self-Efficacy and success career.

Instrumental readiness predisposes entrepreneurial intention through ESE. Instrumental readiness and risk propensity are some crucial elements that have pivotal role in developing entrepreneurial intention and ESE (Indarti \& Kristianten, 2003). 
Many definitions exist about risk-taking propensity. According to (Sitkin \& Pablo, 1995), Risk propensity is self-inclination in avoiding risk. (Lopes, 1986) Risk tendency have a major influence on individual decision-making and behavior. According to (Wenhong \& Liuying, 2010) stated that risk tendencies and risk behavior have a linear correlation. Therefore, the higher risk-seeking tendency, the higher risk-taking behavior.

Individuals with high risk tendency and high self-efficacy are more optimistic in coping with problems or setbacks (Zhao, Seibert, \& Hills, 2005). A study of (Densberg, 2014) suggested that any specific propensity for risk that entrepreneurs may demonstrate is an outcome of their moderately high self-efficacy. The results also indicated that high levels of self-efficacy make entrepreneurs comfortable in taking high risks.

The research model is attached in figure below :

Figure 4 Theoretical Framework

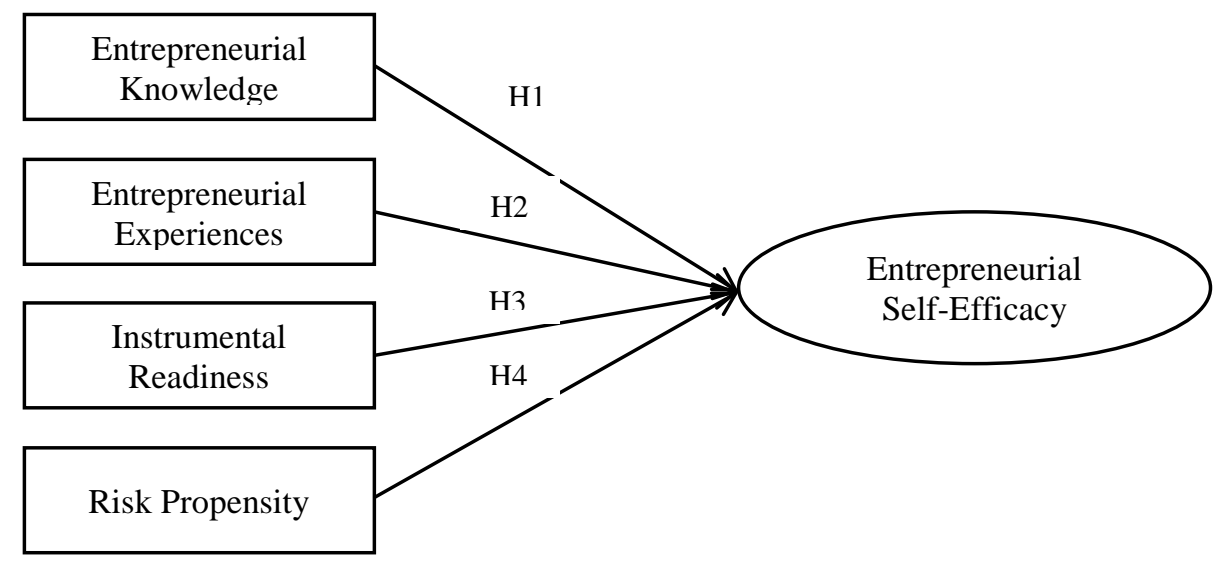

Source : processed data (2021)

\section{Method}

Empirical model of this study is :

$$
\begin{aligned}
& \mathrm{Y}=\mathrm{P} \times 1 \mathrm{y} X 1+\varepsilon 1 \\
& =\mathrm{Px} 2 \mathrm{y} \times 2+\varepsilon 2 \\
& =\text { Px3y X3 }+\varepsilon 3 \\
& =P x 4 y X 4+\varepsilon 4
\end{aligned}
$$

X1 refers to Entrepreneurial Knowledge, X2 refers to Entrepreneurial Experiences, X3 refers to Instrumental Readiness, $X 4$ refers to Risk Propensity and $Y$ refers to Entrepreneurial Self-Efficacy. Pxy is path coefficient from $X$ to $Y$. $\varepsilon$ is epsilon of path coefficient $X$ to $Y$. The data are gathered by spreading 52 questionnaires to owner of Medium and High School Enterprises in Bandung. This study used soft modeling method named Partial Least Square (PLS) to analyze the greatest effect of Entrepreneurial Self- 
Efficacy among the four variables. PLS require $30-100$ samples to be tested (Ghozali, 2008).

\section{Results}

The Impact of Entrepreneurial Knowledge, Entrepreneurial Experiences, Instrumental Readiness, Risk Propensity on the Entrepreneurial Self Efficacy (ESE) can be seen from the table below:

Table 1 Correlation of four variables and ESE

\begin{tabular}{llll} 
Original & Standard & T Statistics & P \\
Sample (O) & $\begin{array}{l}\text { Deviation } \\
\text { (STDEV) }\end{array}$ & (|O/STDEV|) & Values \\
\hline
\end{tabular}

\begin{tabular}{lcccc}
\hline $\begin{array}{l}\text { Entrepreneurial Knowledge -> } \\
\text { Entrepreneurial Self Efficacy }\end{array}$ & $\mathbf{0 , 9 4 8}$ & 0.017 & $\mathbf{5 4 . 2 3 2}$ & 0.000 \\
$\begin{array}{l}\text { Entrepreneurial Experiences -> } \\
\text { Entrepreneurial Self Efficacy }\end{array}$ & $\mathbf{0 . 9 0 8}$ & 0.024 & $\mathbf{3 7 . 0 7 8}$ & 0.000 \\
$\begin{array}{l}\text { Instrumental Readiness -> } \\
\text { Entrepreneurial Self Efficacy }\end{array}$ & $\mathbf{0 . 8 6 6}$ & 0.055 & $\mathbf{1 4 . 6 4 3}$ & 0.000 \\
$\begin{array}{l}\text { Risk Propensity -> } \\
\text { Entrepreneurial Self Efficacy }\end{array}$ & $\mathbf{0 . 9 0 0}$ & 0.032 & $\mathbf{2 6 . 9 5 0}$ & 0.000 \\
\hline
\end{tabular}

Source : processed data, 2021

The previous table shows :

1. Entrepreneurial Knowledge has significant and positive correlation to Entrepreneurial Self Efficacy. Impact Entrepreneurial Knowledge on Entrepreneurial Self Efficacy is $94,8 \%$. When Entrepreneurial Knowledge is high, Entrepreneurial Self Efficacy is high.

2. Entrepreneurial Experiences has significant and positive correlation to Entrepreneurial Self Efficacy. Impact Entrepreneurial Experiences on Entrepreneurial Self Efficacy is $90,8 \%$. When Entrepreneurial Experiences is high, Entrepreneurial Self Efficacy is high.

3. Instrumental Readiness has significant and positive correlation to Entrepreneurial Self Efficacy. Impact Instrumental Readiness on Entrepreneurial Self Efficacy is $86,6 \%$. When Instrumental Readiness is high, Entrepreneurial Self Efficacy is high. 
4. Risk Propensity has significant and positive correlation to Entrepreneurial Self Efficacy. Impact Risk Propensity on Entrepreneurial Self Efficacy is $90 \%$. When Risk Propensity is high, Entrepreneurial Self Efficacy is high.

The correlation among variables and it's cause, shown in the figure below:

The biggest cross loading from outer model shows the biggest causes of the impact from each variables on Entrepreneurial Self Efficacy. The previous figure shows :

1. The biggest cross loading factors of Entrepreneurial Knowledge (X1) is EK9 and EK1. This means that EK9 \& EK1 are the biggest causes of the impact of Entrepreneurial Knowledge on Entrepreneurial Self Efficacy.

2. The biggest cross loading factors of Entrepreneurial Experiences (X2) is EE6 and EE3. This means that EE6 \& EE3 are the biggest causes of the impact of Entrepreneurial Experiences on Entrepreneurial Self Efficacy.

3. The biggest cross loading factor of Instrumental Readiness (X3) is IR5 and IR2. This means that IR5 \& IR2 are the biggest causes of the impact of Instrumental Readiness on Entrepreneurial Self Efficacy.

4. The biggest cross loading factor of Risk Propensity is RP7, RP2 and RP5. This means that RP7, RP2 and RP5 are the biggest causes of the impact of Risk Propensity on Entrepreneurial Self Efficacy.

Figure 5 Outer Model

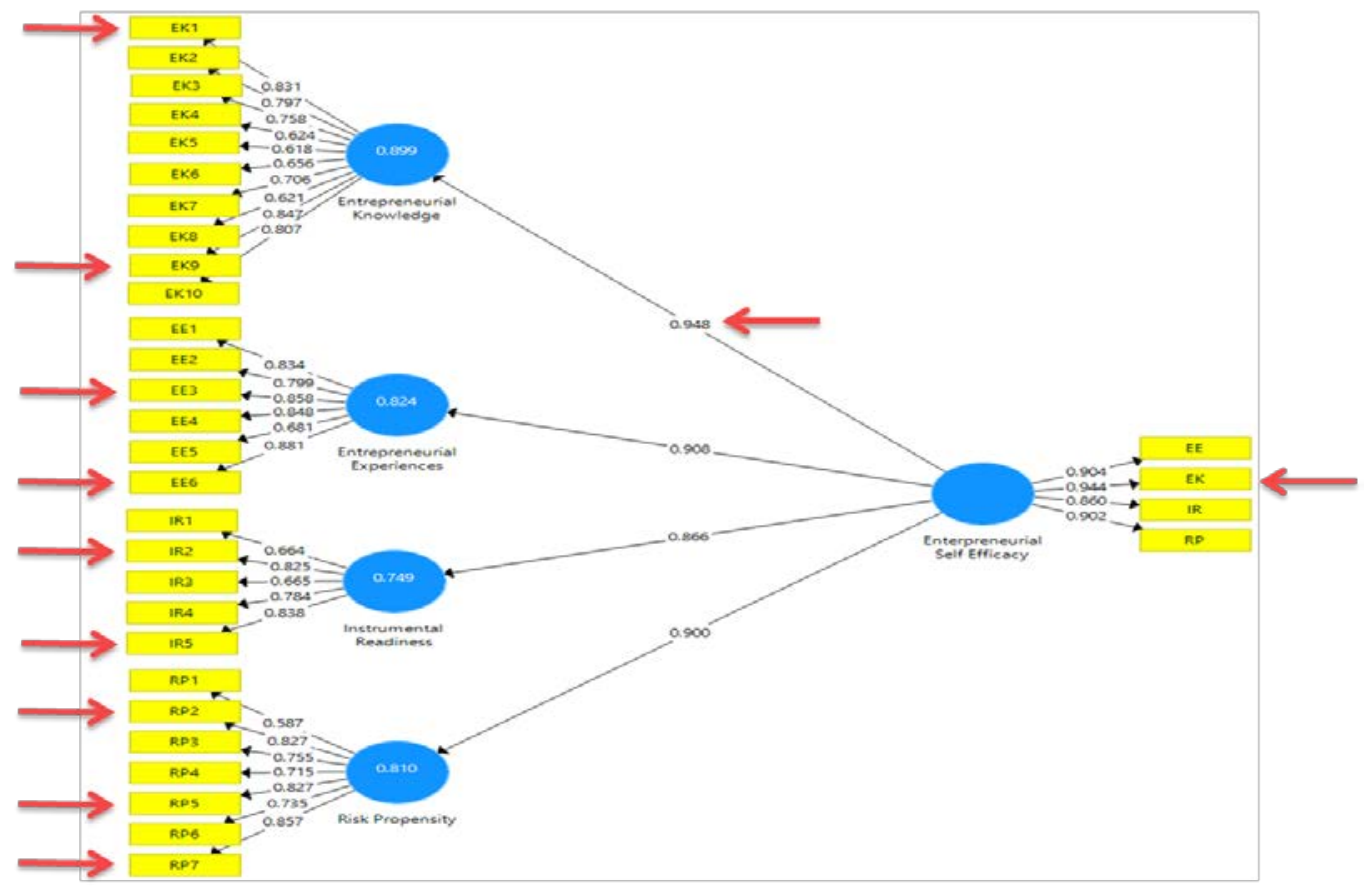

Source: processed data, 2021 


\section{Discussion and Conclusion}

\subsection{Impact Entrepreneurial Knowledge on the Entrepreneurial Self-Efficacy (ESE)}

The empirical results show that Entrepreneurial Knowledge affect ESE positively and significantly. The impact is about $94,8 \%$. It is considered as a strong impact. The biggest cross loading factors of Entrepreneurial Knowledge are EK9 \& EK1. It means Entrepreneurial Knowledge makes Entrepreneurial Self Efficacy of respondents high because they have knowledge to improve their business positively and can promote their product well. Most respondents (46\% of women and $46 \%$ of men) have bachelor degree as their educational background. According to interview with several respondents $(23 / 04 / 2021)$, it is found that they have more confident to overcome business crisis in Covid-19 pandemic era because of they have knowledge about business from college. They apply business strategy such as making innovation, doing online marketing, adding the markets, etc. According to Küttim, Kallaste, Venesaar, \& Kiis, (2014) quoted in (Hutasuhut, 2018) entrepreneurship education has a positive impact towards entrepreneurship. Then (Roxas, 2014) quoted in (Hutasuhut, 2018) states entrepreneurship education significantly increases entrepreneurial knowledge and needs to be developed to keep students confident and willing to engage in entrepreneurship. (Rae \& Carswell, 2000) said that developing entrepreneurial talent through knowledge, skills, expertise, learning can contribute to develop successful business.

Most of respondents (54\% of women and $58 \%$ of men) are $20-30$ years old. It can be associated with the most productive age in entrepreneurship in the age range between 15-64 years. The age is in accordance with the educational background that has been completed from undergraduate studies. From interview with several respondents $(23 / 04 / 2021)$, it is found that they have willingness to continue their study to higher degree or learn new things through other activities (workshop, training, short course) to support their business. According to (Minniti \& Bygrave, 2001), entrepreneurship is a learning practice. It is important to learn entrepreneurial knowledge comprehensively.

\subsection{Impact Entrepreneurial Experiences on the Entrepreneurial Self-Efficacy}

The empirical results show that Entrepreneurial Experiences has significant and positive impact on Entrepreneurial Self-Efficacy. The impact is about $90,8 \%$. It is considered as strong impact. The biggest loading factors of Entrepreneurial Experiences are EE6 \& EE3. It means Entrepreneurial Experiences make Entrepreneurial Self-Efficacy of respondents high because of their experiences in business from their selves or their families can motivate them to develop the business and improve their performance. Most of respondents ( $42 \%$ of men and $54 \%$ of women) had operate their business for three years. According to interview with some respondents (23/04/2021), it is discovered that experience in doing business for 3 years makes them more confident to improve their 
performance and develop their business. They are not only learning business from their own experiences, but also from their families or relatives experiences.

According to (Memon, Soomro, \& Shah, 2019), Self-Efficacy can be developed from forming idea, doing action, obtaining \& conceiving feedback, and growing competencies. (Vaillant \& Lafuente, 2019) also said that experience is an important key in learning entrepreneurship. Even bad experience can be a good teacher in strengthening mental to become tougher entrepreneurs. Less experience in business and seldom obtain feedback about the business performance can decrease Entrepreneurial Self-Efficacy (Dempsey \& Jennings, 2014)

\subsection{Impact Instrumental Readiness on the Entrepreneurial Self-Efficacy}

The empirical results show that Instrumental Readiness has significant and positive impact on Entrepreneurial Self-Efficacy. The impact is about $86,6 \%$. It is considered as strong impact. The biggest loading factors of Instrumental Readiness are EE6 \& EE3. It means Instrumental Readiness make Entrepreneurial Self-Efficacy of respondents high because they can maintain good relationship with partners and identify financial resources for business. Most of respondents ( $42 \%$ of men and $54 \%$ of women) had operate their business for three years. Based on observation on several respondents $(23 / 04 / 2021)$ it is found that financial resources are one of the business foundations. Financial is needed to start, maintain, and develop business. Partners (investor, supplier, distributors, etc.) are also important for business. In order to make successful and sustainable business, entrepreneurs need to maintain their business partners and their financial resources. It is supported by Indarti and Kristiansen (2003), Ramayah and Harunn (2005) in (Memon, Soomro, \& Shah, 2019) who said that Instrumental have an important role in developing Entrepreneurial Self Efficacy.

\subsection{Impact Risk Propensity on the Entrepreneurial Self-Efficacy}

The empirical results show that Risk Propensity has significant and positive impact on Entrepreneurial Self-Efficacy. The impact is about $90 \%$. It is considered as strong impact. The biggest loading factors of Risk Propensity are RP7, RP5, \& RP2. It means Risk Propensity make Entrepreneurial Self-Efficacy of respondents high because they can organize loan for investments and a risk taker in business will make them improve profit in every conditions. Based on interviews with some of respondents (23/04/2021), they said that they need to become risk taker in doing business. Some of respondents take loan from bank or other financial institution for investments such as open new store, restaurants, booth or just to survive in economic crisis. With their knowledge from college and experience in doing business, they confident that they can manage the loan properly to gain profit and to improve their business. It is supported by Zhao et al.(2005), Hmieleski and Corbett (2006), Barbosa et al.(2007) in (Memon, Soomro, \& 
Shah, 2019) who said that the individual who can coping with setbacks is a person that has high self-efficacy, risk-taking propensity, and optimism.

Risk propensity relationship has a positive effect and correlates with entrepreneurial activities (Kaldana and Ruzzier 2012). In other research by (Reichert, Bird and Farber 2021) indicate that in normal or low-risk situations, women entrepreneurs doing businesses for social purposes. While male entrepreneurs doing businesses with commercial purposes, in extreme situation, male entrepreneurs prefer doing business with social purposes.

\subsection{Comparison Between Women and Men Entrepreneurs}

Both Men and Women Entrepreneurs have Entrepreneurial Knowledge as the most influence factor of their Entrepreneurial Self-Efficacy.

But some of their characteristics are different. There are the characteristics are presented in table 2.

Table 2 respondent's characteristics

\begin{tabular}{ccc}
\hline CHARACTERISTIC & MEN ENTREPRENEURS & $\begin{array}{c}\text { WOMEN } \\
\text { ENTREPRENEURS }\end{array}$ \\
AGE & 20-30 years old (58\%) & 20-30 years old (54\%) \\
EDUCATION & Bachelor Degree (46\%) & Bachelor Degree (46\%) \\
BUSSINESS FIELD & Fashion (54\%) & Fashion (54\%) \\
BUSSINESS OPERATIONS & More than 3 years (42\%) & More than 3 years (54\%) \\
$\begin{array}{c}\text { MAIN PURPOSE OF } \\
\text { BUSSINESS }\end{array}$ & As main income (50\%) & $\begin{array}{c}\text { As additional income } \\
\text { (46\%) }\end{array}$ \\
$\begin{array}{c}\text { REASON OF DOING } \\
\text { BUSNIESS }\end{array}$ & $\begin{array}{c}\text { Have more income and } \\
\text { self actualization (92\%) }\end{array}$ & $\begin{array}{c}\text { Have more income and } \\
\text { doing hobbies (73\%) }\end{array}$ \\
\hline
\end{tabular}

Source: (Processed Data, 2021)

For women entrepreneurs, doing business are just additional activities to make more money or to do hobbies. Based on direct observation on some woman entrepreneurs $(23 / 04 / 2021)$, they said that the main breadwinner in their families are their husbands. They are doing business just to be more productive in their free time, have status society, or get extra income to be more independent. Just several of them that become the main breadwinner for the families. For men entrepreneurs, doing business are their main activities to make money and for self actualization. Based on direct observation on 
some man entrepreneurs (23/04/2021), they said that they are the main breadwinner in their families, so they need to make the business succeed. Their doing business for the future and happiness of their families. For them, business is main activities to do and their goals in life. It makes them more struggle in running their business (more intentions and actions in business). It is supported by (Baughn et al. 2006; Minitti and Bygrave 2003; Wilson, Marlino, and Kickul 2004; Zhao, Seibert, and Hills 2005), who said that women has lower intention to take entrepreneurial action than men. It is also supported by (Intan \& Elisa, 2015) who stated that several reasons people become entrepreneurs are financial, social, community service, and self-fulfilment.

\subsection{Conclusion}

This study found that ESE is affected by entrepreneurial knowledge, entrepreneurial experience, instrumental readiness and risk propensity significantly and positively. Entrepreneurial Knowledge is the most influence factor among all factors. It is in accordance with the statement of Küttim, Kallaste, Venesaar, \& Kiis, (2014) and Roxas (2014) in (Hutasuhut, 2018), which is said entrepreneurship education has positive and significant impact on entrepreneurial knowledge. It needs to be developed to maintain entrepreneurial self-efficacy. Rae \& Carswell (2000) in (Memon, Soomro, \& Shah, 2019) said that successful business can be obtained by developing entrepreneurial talent through knowledge, skills, expertise, learning.

Both of Men and Women Entrepreneurs have Entrepreneurial Knowledge as the biggest influence of their Entrepreneurial Self-Efficacy. But Men and Women have several different characteristics; in the purpose and the reason of doing Business. Doing Business are the main activity to make money for men entrepreneurs and for their selfactualization. While for women entrepreneurs, doing business is just additional activities to make more income, gain status in society, or fill their free time with productive activities. It is supported by (Intan \& Elisa, 2015) who said that some reasons for people become entrepreneurs are financial, social, service, and self-fulfilment. Most women entrepreneur of respondents are doing business because of social and self-fulfilment reasons. Most of men entrepreneur of respondents are doing business because of financial reasons.

\section{Acknowledgement}

This research is the output of Internal Research Grant Program form Ministry of Education, Research, Research, and Technology. Therefore, I would like to thank the Ministry of Education, Culture, Research, and Technology for funding this research to completion. Hopefully this research can be a reference for various parties and can contribute to the scientific repertoire. 


\section{References}

Gu, C., \& Lin, S. (2020). Size, Entrepreneurial Experience and Organizational Decentralization. Chinese Management Studies, 1750-614X.

Bisnis.com. $\quad(2020,10 \quad 2) . \quad$ Retrieved $7 \quad 12, \quad 2021$, from https://bandung.bisnis.com/read/20201002/550/1299722/6000-umkm-terdampakpandemi-dinas-kumkm-bentuk-umkm-recovery-center

BPS.go.id. (2021, 2 5). Retrieved $7 \quad 1$, 2021, from https://www.bps.go.id/pressrelease/2021/02/05/1811/ekonomi-indonesia-2020-turunsebesar-2-07-persen--c-to-c-.html

diskopumkm.bandung.go.id. (2021, $7 \quad$ 1). Retrieved $7 \quad 1$, 2021, from http://diskopumkm.bandung.go.id/page/informasi-umkm

JabarEkspres.com. $\quad(2021, \quad 3 \quad 24)$. Retrieved $7 \quad 1$, 2021, from https://jabarekspres.com/berita/2021/03/24/capai-38-persen-laju-pertumbuhanumkm-di-kota-bandung/

Lokadata.id. (2021, February 8). Retrieved 7 1, 2021, from https://lokadata.id/data/pendapatanper-kapita-indonesia-2015-2020-1612762226

Tagar.id. (2021, 2 21). Retrieved 12 7, 2021, from https://www.tagar.id/dampak-pandemicovid19-banyak-umkm-di-jabar-gulung-tikar

Worldometers.info. (2021, 7 1). Retrieved 7 1, 2021, from https://www.worldometers.info/worldpopulation/indonesia-population/

Alberti, F. (1999). Entrepreneurship education: scope and theory', in Salvate, C., Davidsson, P. and Persson, A. (Eds.): Entrepreneurial Knowledge and Learning: Conceptual Advances and Directions for Further Research. JIBS Research Reports, 64-84.

Bandura, A. (1982). Self-Efficacy Mechanism in Human Agency. American Pychologist, 37(2), 122147.

Baughn, C. C., Cao, J. S., Le, L. T., Lim, V. A., \& Kent, N. E. (2006). NORMATIVE, SOCIAL AND COGNITIVE PREDICTORS OF ENTREPRENEURIAL INTEREST IN CHINA, VIETNAM AND THE PHILIPPINES. Journal of Developmental Entrepreneurship, 11(1), 57-77.

Bergman, N., Rosenblatt, Z., Erez, M., \& De-Haan, U. (2011). Gender and The Effects of an Entrepreneurship Training Programme on Entrepreneurial Self-Efficacy . Int. J. Entrepreneurship and Small Business, Vol. 13, No. 1, 38-54.

Boyd, N., \& Vozikis, G. (1994). The Influence Of Self-Efficacy On The Development Of Entrepreneurial Intentions And Actions. Entrepreneurship Theory and Practice, 18(4), 6378.

Chen, C. C., Greene, P. G., \& Crick, A. (1998). Does entrepreneurial self-efficacy distinguish entrepreneurs from managers? Journal of Business Venturing, 13(4), 295-316.

Chowdhury, S., Endres, M. L., \& Frye, C. (2018). The influence of knowledge, experience, and. Journal of Small Business \& Entrepreneurship, 1-19.

Coleman, S., \& Kariv, D. (2014). Deconstructing' entrepreneurial self-efficacy: a gendered perspective on the impact of ESE and community entrepreneurial culture on the financial strategies and performance of new firms. International Journal of Entrepreneurial Finance, 16(2), 157-181.

Dempsey, D., \& Jennings, J. (2014). Gender and Entrepreneurial Self-Efficacy: A Learning Perspective. International Journal of Gender and Entrepreneurship. Vol. 6 No. 1, 28-49.

Densberg, K. (2014). The Self-Efficacy And Risk-Propensity Of Entrepreneurs. Journal of Enterprising Culture, 22(4), 437-462. 
Dervojeda, K., Verzijl, D., Nagtegaal, F., Lengton, M., \& Rouwmaat, E. (2014). Innovative Business Models: Supply chain finance. Netherlands: Business Innovation Observatory; European Union.

Gano-an, J. (2020). THE DEFINING MOMENTS OF BUSINESS SUCCESS AMONG WOMEN MICROENTREPRENEURS. Review Behavioral Aspect in Organization \& Society, 95-112.

Gano-an, J. C. (2020). The Defining Moments of Business Success Among Women MicroEntrepreneurs: A Literature Review and Future Directions. Review Of Bahavioral Aspect in Organizations \& Society, 2(2), 95-112.

Gano-an, J. C. (2020). THE DEFINING MOMENTS OF BUSINESS SUCCESS AMONG WOMEN MICROENTREPRENEURS: A LITERATURE REVIEW AND FUTURE DIRECTIONS. Review of Behavioral Aspect in Organizations \& Society, 2(2), 95-112.

Hao, Z., Scott, S., \& Gerald, H. (2005). The Mediating Role of Self-Efficacy in the Development of Entrepreneurial Intentions. Journal of Applied Psychology, 90(6), 1265-1272.

Hutasuhut, S. (2018). The Roles of Entrepreneurship Knowledge, Self-Efficacy, Family, . Dinamika Pendidikan. Vol. 13, No. 1, 90-105.

Indarti, N., \& Kristianten, S. (2003). Determinants of Entrepreneurial Intention: tTe Case of Norwegian Students. Gajahmada International Journal of Business, 5(1), 79-95.

Intan, H., \& Elisa. (2015). Analisis Alasan Berwirausaha Terhadap Keputusan Pelaksanaan Bisnis Sampingan (Pada Pemiliki Bisnis di Kawasan Sekitar Kambang Iwak dan Jalan Balap Speda POM-X Palembang). Jurnal Manajemen dan Bisnis Sriwijaya. Vol.13 No.2, 155176.

Kaldana, L., \& Ruzzier, M. (2012). Risk Propensity as Entrepreneurial Characteristic : The Case of Slovenian Students of Business and Economics Studies. Int. J. Management in Education, Vol. 6, No. 4, 363-381.

Kazeem, A. A., \& Asimiran, S. (2016). Factors Affecting Entrepreneurial Self-efficacy of . International Journal of Academic Research in Business and Social Sciences, 519 - 534.

Kazeem, A. A., \& Asimiran, S. (2016). Factors Affecting Entrepreneurial Self-efficacy of Engineering Students. International Journal of Academic Research in Business and Social Sciences, 519 - 534.

Kazeem, A. A., \& Asimiran, S. (2016). Factors Affecting Entrepreneurial Self-efficacy of Engineering Students. International Journal of Academic Research in Business and Social Sciences, 519 - 534.

Krueger, N. F., \& Brazeal, D. V. (1994). Entreprenurial Potetia and Potential Entrepreneurs. Spring, 91-104.

Lopes, L. L. (1986). Between Hope And Fear: The Psychology of Risk. Advances in Experimental social Psychology, 20, 255-295.

Maqsood Memon, B. A. (2019). Enablers of entrepreneurial. Education +Training, 1-17.

Maritz, A., \& Brown, C. (2013). Enhancing entrepreneurial self-efficacy through vocational. Journal of Vocational Education and Training, Vol. 65, No. 4, 543-559.

Memon, M. S. (2019). Enablers of entrepreneurial. Education + Training, 1-17.

Memon, M., Soomro, B. A., \& Shah, N. (2019). Enablers of entrepreneurial. Education + Training, Vol. 61 No. 6, 1-17.

Minniti, M., \& Bygrave, W. (2001). A Dynamic Model of Entrepreneurial Learning. Entrepreneurship Theory and Practice, 25(3), 5-16.

Pihie, Z. A., \& Bagheri, A. (2010). Entrepreneurial attitude and entrepreneurial efficacy of technical. Journal of Vocational Education and Training, 62(3), 351-366. 
Puni, A., Anlesinya, A., \& Korsorku, P. D. (2018). Entrepreneurial education, self-efficacy and intentions in Sub-Saharan Africa. African Journal of Economic and Management Studies,, 9(4), 492-511.

Rae, D., \& Carswell, M. (2000). Using a Life-Story Approach in Researching Entrepreneurial Learning: The Development of a Conceptual Model and Its Implications in The Design of Learning Experiences. Education + Training, 42(4/5), 220-227.

Reichert, P., Bird, M. D., \& Farber, V. (2021). Gender and Entrepreneurial Propensity: Risk-Taking and Prosocial Preferences in Labour. Social Enterprise Journal. Vol. 17, No. 1, 111-139.

Sitkin, S. B., \& Pablo, A. L. (1995). Determinants Of Risky Decision-Making Behavior: S Test Of The Mediating Role Of Risk Perceptions And Propensity. Academy of Management Journal, 38, 1573-1592.

Sukmaningrum, A., \& Imron, A. (2017). MEMANFAATKAN USIA PRODUKTIF DENGAN USAHA KREATIF INDUSTRI PEMBUATAN KAOS . Paradigma. Vol. 05, No. 03, 1-6.

Vaillant, Y., \& Lafuente, E. (2019). Entrepreneurial Experience and The Innovativeness of Serial Entrepreneurs. Management Decision. Vol. 57 No. 11, 0025-1747.

Wenhong, Z., \& Liuying, F. (2010). The Impact of Entrepreneurial Thinking System on Risk-Taking Propensity and Entrepreneurial Behavior. Journal of Chinese Entrepreneurship, Vol. 2, No. 2, 165-174.

Zhao, H., Seibert, S., \& Hills, G. (2005). The Mediating Role of Self-Efficacy In The Development Of Entrepreneurial Intentions. Journal of Applied Psychology, 90(6), 1265-1272. 